NBER WORKING PAPER SERIES

\title{
CAPITAL ACCOUNT LIBERALIZATION, FINANCIAL DEPTH, AND ECONOMIC GROWTH
}

\author{
Michael Klein \\ Giovanni Olivei \\ Working Paper 7384 \\ http://www.nber.org/papers/w7384
NATIONAL BUREAU OF ECONOMIC RESEARCH
1050 Massachusetts Avenue
Cambridge, MA 02138
November 2005

We thank Catherine Humblet for excellent research assistance. Opinions expressed in this paper are those of the authors and do not necessarily reflect the views of the Federal Reserve Bank of Boston, the NBER, or of the Federal Reserve System. The views expressed herein are those of the author(s) and do not necessarily reflect the views of the National Bureau of Economic Research.

(C)1999 by Michael Klein and Giovanni Olivei. All rights reserved. Short sections of text, not to exceed two paragraphs, may be quoted without explicit permission provided that full credit, including (C) notice, is given to the source. 
Capital Account Liberalization, Financial Depth, and Economic Growth Michael Klein and Giovanni Olivei

NBER Working Paper No. 7384

October 1999, Revised June 2006

JEL No. F36, F43

\begin{abstract}
We show a statistically significant and economically relevant effect of open capital accounts on financial deepness and economic growth in a cross-section of countries over the period 1986 to 1995. Countries with open capital accounts over some or all of this period had a significantly greater increase in financial depth than countries with continuing capital account restrictions, and they also enjoyed greater economic growth. The results, however, are largely driven by the developed countries in the sample. The observed failure of capital account liberalization to promote financial deepness among developing countries suggests potentially important policy implications concerning the desirability of liberalizing the capital account.
\end{abstract}

Michael W. Klein

The Fletcher School

Tufts University

Medford, MA 02155

and NBER

mklein@tufts.edu

Giovanni Olivei

Research Department

Federal Reserve Bank of Boston

600 Atlantic Avenue

Boston, MA 02106

giovanni.olivei@bos.frb.org 


\section{Introduction}

By the end of the twentieth century, governments of industrial countries had virtually eliminated all policies hindering the movement of financial capital across their borders. Basic economic theory suggests ways in which capital account liberalization may benefit a country: Free capital mobility offers the opportunity to realize the highest return on saving, to borrow at the most favorable rates, and to diversify away countryspecific risk. ${ }^{1}$ A more subtle set of benefits, but ones that have increasingly been the focus of discussion, pertain to the impact of capital account liberalization on the efficiency and development of a country's financial system. The potential relevance of this channel is highlighted by recent work on the importance of financial development for economic growth. ${ }^{2}$

There are a number of channels through which capital account liberalization can contribute to the development of a country's financial system. Exposure to international competition may improve the efficiency of the domestic financial system via the introduction of international standards as well as through the potential threat of "flight to quality" posed by foreign intermediaries. Subsidiaries or branches of foreign banks may enlarge the absolute size of the national banking system, serve formerly neglected niches of the market, and introduce financial innovation that directly broadens the scope of financial services. These gains in the efficiency and scope of the financial sector may

\footnotetext{
${ }^{1}$ Two surveys of the empirical literature on the role of capital account liberalization on growth are Edison, Klein, Ricci and Sløk (2004) and Prasad, Rogoff, Wei and Kose (2003).

${ }^{2}$ Empirical studies documenting the contributions of financial intermediaries to economic growth include McKinnon (1973), King and Levine (1993), Rajan and Zingales (1998), and Levine, Loayza, and Beck (2000). See also the review paper by Levine (1997). The theoretical foundations of financial intermediation's role in economic development are discussed by, among others, Bagehot (1873), Schumpeter (1912), Hicks (1969), Greenwood and Jovanovic (1990) and Bencivenga and Smith (1991).
} 
increase the pool of available savings both by eliciting higher domestically generated savings and by promoting capital inflows. And, in a virtuous cycle, increased savings may in turn promote further efficiency by enabling intermediaries to reap significant economies of scale and scope. ${ }^{3}$

In this paper we examine whether there is evidence of a link from capital account liberalization to financial depth and, through this channel, to overall economic growth. ${ }^{4}$ Using a wide cross-section of countries, we show that countries with open capital accounts have significantly greater financial depth than countries with capital account restrictions. Estimates indicate an economically important and statistically significant effect of capital account liberalization on economic growth through the deepening of a country's financial market. We also show, however, that the significance of the link between capital account convertibility and financial depth seems to be driven largely by the industrialized countries included in the cross-section. Therefore, one possible interpretation of our findings is that countries require a constellation of economic, legal, and social institutions in order to have capital account liberalization translate into greater

\footnotetext{
${ }^{3}$ See de Swaan (1999). Addressing these points, Summers (2000) writes: “...to the extent that international financial integration represents an improvement in financial intermediation, ... [perhaps] because institutions involved in the transfer of capital across jurisdictions improve efficiency with which capital is allocated, it offers a potentially significant increase in economic efficiency. ... [F]inancial flows ... finance real trade, ... provide capital to local businesses on what are often the best available terms ... [and] are closely associated with the presence of foreign businesses and foreign financial institutions, which themselves bring significant benefits." (p. 3)

4 Two works related to ours include De Gregorio (1999) and Chinn and Ito (2002). De Gregorio analyzes the effect of financial integration on financial depth and, through this channel, on overall growth. Our study differs from his in that we use a wider set of countries, a different measure of financial integration, and a different empirical specification. Chinn and Ito's empirical analysis of the effect of capital account liberalization on financial development is similar to ours. We differ by using a pure cross-sectional approach, whereas Chinn and Ito rely on panel data techniques.
} 
financial depth. ${ }^{5}$ These institutions tend to be present in industrial countries but are less common among developing countries.

The rest of the paper proceeds as follows. Section 2 presents the data used in the empirical analysis. Section 3 examines the effect of capital account liberalization on financial depth in a wide cross-section of developed and developing countries. Section 4 assesses the impact of capital account liberalization on overall economic growth through the financial deepening channel by estimating a simultaneous equation model in which financial depth and economic growth are jointly determined. Section 5 offers some concluding remarks.

\section{Measures of Financial Depth and Capital Account Liberalization}

It is difficult to construct a single quantitative measure that captures the extent to which financial markets in a country fulfill their potential roles, a difficulty compounded when studying a widely heterogeneous set of countries. Likewise, there are several ways to gauge the ease with which assets are traded across a country's border. Our indicators of financial depth and capital account liberalization largely follow those used in previous research. Descriptive statistics of these data, presented in this section, foreshadow some of the themes raised in the regression analysis, including differences between industrial and developing countries and patterns of capital account liberalization.

\section{Financial Depth}

Several measures of financial development have been proposed in the empirical literature. In our work, we focus on two indicators of financial intermediary development,

\footnotetext{
${ }^{5}$ The need for the presence of well-functioning economic, social, and legal institutions in order to reap the benefits from opening an economy has been stressed by, among others, Rodrik (1999) and Klein (2005).
} 
with each indicator constructed in such a way that an increase reflects greater financial depth. $^{6}$

The liquid liabilities indicator, $L L Y$, represents the ratio of liquid liabilities to $G D P$, where liquid liabilities consist of currency held outside the banking system plus demand and interest-bearing liabilities of banks and non-bank financial intermediaries. Thus, $L L Y$ is a typical measure of financial depth since it reflects the overall size of the financial intermediary sector. It does not, however, distinguish between the allocation of capital to the private sector and to various governmental and quasi-governmental agencies. In an effort to isolate credit issued to the private sector from that issued to governments, government agencies, and public enterprises, we also employ the indicator PRIVY, which equals the ratio of claims by financial intermediaries to the private sector to GDP. Typically, this is the indicator of financial development preferred in the empirical literature. $^{7}$

We will study the effect of capital account liberalization over the period 1986 to 1995, and over the period 1975 to 1995 , on a country's average level of financial depth during the years 1991-1995. We focus on this average level rather than the measured level of financial depth in 1995 , the last year of our sample, in order to minimize random variations in our indicators of financial depth. ${ }^{8}$

\footnotetext{
${ }^{6}$ It is plausible, at least in principle, that financial integration has an impact not only on the development of financial intermediaries, but also on the development of a country's stock and bond market (Levine and Zervos 1998). We limit our analysis to indicators of financial intermediary development since this allows us to consider a wider set of countries.

${ }^{7}$ See, for example, Levine, Loayza and Beck (2000).

${ }^{8}$ As we explain later in the text, the sample ends in 1995 because the measurement of our indicator of capital account openness changed after this date in a way that makes the post-1995
} 
Table 1 presents summary statistics on $L L Y$ and $P R I V Y$, both for the full sample of countries and for the separate samples of industrial and developing countries. ${ }^{9}$ The correlation between these two indicators is greater than 70 percent for both OECD and non-OECD samples. Both measures of financial development indicate greater financial depth among the 21 OECD countries than among the 74 non-OECD countries in our sample. In addition, while the OECD countries experienced sizable financial deepening over the period 1986 to 1995 , there were much smaller increases in both measures of financial depth among the countries that constitute the non-OECD sample. In contrast, non-OECD countries experienced a faster rate of financial deepening over the previous decade, 1976 to 1986, than did the OECD countries. This difference in the time-series evolution of our indicators of financial depth is one reason for assessing the effect of capital account liberalization on financial deepening over different sample periods. ${ }^{10}$

\section{Capital Account Liberalization}

Given the diversity in the intensity and scope of capital controls, it is difficult to obtain a consistent measure of capital account restrictions across a wide range of countries. We follow the majority of studies on capital account liberalization in using annual data from the International Monetary Fund's publication Exchange Arrangements

values of this series incommensurate with the earlier values. Furthermore, the rise of emerging markets in the early 1990s makes this period a focus of interest.

${ }^{9}$ In this paper, OECD member countries are those that were in the OECD in 1986. The appendix includes the list of countries and notes those that are classified as OECD members as well as those that, for reasons of data availability, are not included in the 1976 - 1995 sample but only in the shorter 1986 - 1995 sample.

${ }^{10}$ The results discussed here are robust to using the same sample for the shorter period as is available for the longer period. 
and Exchange Restrictions. ${ }^{11}$ One advantage of these data is that they provide a consistent measure over a wide range of countries. Another advantage is that they are available on an annual basis. Their major disadvantage is that, until 1996, they provided only the broadest indication of a country's stance towards the free movement of capital. The indicators before 1996 did not distinguish between restrictions on different types of capital flows or even between restrictions on inflows of capital and restrictions on outflows of capital. The more recent (from 1996 on) IMF data include greater detail, but it is still impossible to directly measure the intensity of controls or their efficacy. Also, because we cannot reliably map the new classification system into a qualitative set of indicators that matches the older classification system, our empirical analysis focuses on the pre-1996 period.

From the Exchange Arrangements and Exchange Restrictions we generate a simple $0 / 1$ indicator variable for each country for each year. ${ }^{12}$ This indicator takes the value of 1 if the country had no capital controls in place. Then, for each country, we calculate the variable $K A L I B$, which represents the proportion of years in which the country had unrestricted capital mobility. This method of taking the share of years over a period during which the capital account was open has been used by Grilli and MilesiFerretti (1995), Rodrik (1998), and Klein (2005), among others.

Panel $A$ of Table 2 lists the value of $K A L I B_{86-95}$ for countries included in next section's regression analysis that had some experience with open capital accounts (that is,

\footnotetext{
${ }^{11}$ Edison, Klein, Sløk and Ricci (2004) show that there is a high correlation between the indicator of capital account openness used in this paper and the one developed by Dennis Quinn (1997), which is the other indicator most often used in empirical analysis. The Quinn indicator is available for a smaller set of countries than the indicator used in this paper.

${ }^{12}$ The appropriate information is in line E2 in the Summary Table of Exchange Arrangements and Exchange Restrictions.
} 
$K A L I B_{86-95}$ ? 0) over the period 1986 to 1995 . This panel shows that $K A L I B_{86-95}$ equals 1 for 9 OECD countries (out of a possible 21) and 7 non-OECD countries (out of a possible 74). While 58 non-OECD countries had restricted capital account for this entire period, the same is true for only 2 OECD countries, Greece and Iceland.

While the definition of $K A L I B$ does not necessarily reflect the timing of capital account liberalization, the data in the table nonetheless show a correspondence between $K A L I B_{86-95}$ and the actual years during which the capital account was open. For example, all the countries for which $K A L I B_{86-95}=0.1$ had open capital markets in 1995 only; the countries for which $K A L I B_{86-95}=0.2$ had open capital markets in 1994 and 1995; the countries for which $K^{\prime} A L I B_{86-95}=0.3$ had open capital markets in 1993 to 1995 ; and so on. This relationship generally holds across all values of $K A L I B_{86-95}$ with only two cases of on-again, off-again capital account liberalization, Ecuador and Uruguay.

Panel $B$ of Table 2 shows that there were also no instances of on-again, off-again capital account liberalization for OECD countries if we extend the sample period back to 1976. However, 10 of the 18 non-OECD countries that had some experience with liberalized capital accounts in the period between 1976 and 1984, reimposed restrictions at some time over the sample period. ${ }^{13}$ Thus, for non-OECD countries, there is a weaker correspondence between the timing of capital account liberalization and the twenty-year indicator, $K A L I B_{76-95}$ than is the case with the indicator based on the shorter sample period, $K A L I B_{86-95}$. Because of this weaker correspondence, in the next section we present regression results for the 1986 to 1995 sample period, as well as for the twentyyear sample.

\footnotetext{
${ }^{13}$ The five non-OECD countries that had continuously open capital accounts over the period 1976 to 1995 are Bahrain, Indonesia, Malaysia, Panama, and Saudi Arabia.
} 


\section{Capital Account Liberalization and Financial Depth}

In this section we provide evidence of a systematic association between capital account liberalization and financial depth, and show that such a result is robust to different estimation techniques, to changes in the sample period, and to the inclusion of variables controlling for other types of policy changes or cross-country differences in institutional factors. However, we also show that the findings are largely driven by the responsiveness of financial depth to capital account liberalization among OECD countries.

\section{Specification and Basic Results}

Financial depth is typically used as an exogenous regressor to explain economic growth. The focus of this section, however, is to explain the determinants of financial depth. In the absence of a theoretical model that offers a clear explanation of these determinants, but with a focus on the possible role of capital account liberalization on promoting financial depth, we use the following specification of the determinants of the average level of financial depth in a country over the period 1991 to 1995 ,

$$
F D_{1990 s}^{i}=\beta_{0}+\beta_{1} K A L I B_{j}^{i}+\beta_{2} \mathbf{X}^{i}+\varepsilon^{i}
$$

where, $F D_{1990 s}^{i}$ is country $i$ 's measure of average financial depth for the period 1991 to 1995 (that is, $L L Y_{1990 s}^{i}$ or $P R I V Y_{1990 s}^{i}$ ), KALIB ${ }_{j}^{i}$ indicates country $i$ 's stance in terms of capital account liberalization over the period $j$, where $j$ is either the period 1976 to 1995 , or the period 1986 to $1995, \mathbf{X}^{i}$ represents a vector of other explanatory variables, and $\varepsilon^{i}$ is an error term. In our simplest specification, the vector of controls $\mathbf{X}^{i}$ includes indicator 
variables for the regions of Africa and Latin America and an indicator variable identifying oil producing nations, Oil. ${ }^{14}$ The vector $\mathbf{X}^{i}$ also includes the variable Trade ${ }_{k}$, representing the ratio of the sum of a country's exports plus imports to its national income for either $k=1976$ (for the regressions that cover the period 1976 to 1995) or $k=1986$ (for the 1986 to 1995 sample). We include the initial level of trade as a control in the regression because trade may be positively associated with both financial depth (high openness to trade may require a more developed financial system) and an open capital account (international financial flows may finance real trade). Moreover, there is a range of other country-specific factors that likely influences financial depth. In an effort to address the possibility of omitted variable bias, we include financial depth at the beginning of the period (that is, either $L L Y_{1976}^{i}$ or $P R I V Y_{1976}^{i}$ for the 1976 to 1995 sample, or $L L Y_{1986}^{i}$ or $P R I V Y_{1986}^{i}$ for the 1986 to 1995 sample) as an additional control in $\mathbf{X}^{i}$.

Results based on this core specification are presented in Table 3. Columns 1 and 2 report OLS estimates using the 1986 to 1995 sample, for the regressions using LLY and PRIVY, respectively, while Columns 3 and 4 present OLS estimates that use the 1976 to 1995 sample for these two measures of financial depth. The estimates in the table show a positive relationship between a country's degree capital account openness and its level of financial development. In each of the regressions, the coefficient on $K A L I B$ is positive and significant at better than the 98 percent level of confidence. This influence of capital account liberalization on financial depth occurs while controlling for the initial level of

\footnotetext{
${ }^{14}$ The eight oil-producing countries in our sample are Algeria, Bahrain, Republic of Congo, Gabon, Indonesia, Nigeria, Saudi Arabia, and Venezuela.
} 
financial depth, which is itself a significant determinant of the average level of financial depth in the first half of the 1990s.

One way to gauge the magnitude of the effect of capital account liberalization on financial depth is to consider the estimated difference in financial depth between a country that had a closed capital account throughout the period and one that had an open capital account, holding constant the other variables included in the regression. For example, the estimated difference in $P R I V Y_{1990 s}^{i}$ for a country that had an open capital account, as compared to one that had a closed capital account throughout the period, ceteris paribus, is 0.126 . This represents the difference between a country at the median level of $P R I V Y_{1990 s}^{i}$ and one at the $64^{\text {th }}$ percentile. A comparable calculation for $L L Y_{1990 s}^{i}$, using the estimates from the 1986 to 1995 sample, gives a difference between a country at the median level of $L L Y_{1990 s}^{i}$ and one at the $61^{\text {st }}$ percentile. The estimates from the longer sample show an even larger gain for both indicators of financial depth. ${ }^{15}$

We have shown in the previous section that virtually all OECD countries had some experience with capital account liberalization, but there is a relatively small number of non-OECD countries that liberalized their capital accounts at any time before 1995. The question thus arises as to whether the finding of a significant and sizable effect of capital account liberalization on financial depth reflects the influence of a restricted set of countries or rather a more general tendency in the entire cross-section. Therefore, we next investigate whether the responsiveness of financial depth to capital account liberalization differs between the 21 OECD-member countries and the other countries in the sample by

\footnotetext{
${ }^{15}$ The results from the 1976 to 1995 sample show that the estimated difference attributable to having an open, rather than a closed, capital account moves a country from the median value of financial depth to the $64^{\text {th }}$ percentile for $L L Y$, and to the $71^{\text {st }}$ percentile for PRIVY.
} 
introducing an interaction term between $K A L I B_{j}^{i}$ and a dummy variable that equals 1 for each of the 21 OECD member countries. Results of this exercise are reported in Table 4. These results indicate that, indeed, it is the experience of the OECD countries that contributes to the significant effect of capital account liberalization on financial depth. The coefficient on $K A L I B_{j}^{i}$ itself is not significant at the 95 percent confidence level in any of the four regressions, while the sum of the coefficient on $K A L I B_{j}^{i}$ and the coefficient on the interaction between $K A L I B_{j}^{i}$ and the OECD dummy variable is significant at better than the 99 percent level of confidence in all four regressions reported in this table. ${ }^{16}$

The statistically significant results for the OECD countries also are of a magnitude that gives them economic relevance. For example, Australia and Sweden had comparable levels of financial depth in 1986, as measured by $P R I V Y_{86}$, which was 0.385 for Australia and 0.391 for Sweden. Australia had an open capital account in every year of the decade 1986 to 1995 while the capital account of Sweden was only open over the final three years of this period. The predicted difference in $P R I V Y_{1990 s}^{i}$ across these two countries is $0.285 \times(1-0.3)=0.200$, which is close to the actual difference of 0.210 .

These results raise the question of what features enable OECD countries to benefit from an open capital account. One possibility is that higher institutional quality in the OECD countries contributes to the positive responsiveness of financial depth to capital

\footnotetext{
${ }^{16}$ One potential explanation for the lack of significant results in the non-OECD subsample is that some of the countries had an on-again, off-again experience with capital account liberalization. While this could account for the findings for the 1976 to 1995 sample, we here note that omitting Ecuador and Uruguay (the only two countries with on-again, off-again liberalization in the post1985 period) from the 1986 to 1995 sample does not significantly alter the results reported in the first two columns of Table 4.
} 
account liberalization. To investigate this possibility, we modify our baseline specification by adding an indicator of a country's institutional quality and an interaction term between this indicator and $K A L I B_{j}^{i}$ to the regressors. The indicator of institutional quality we use, labeled Govrep, is an index of the likelihood that a country's government will not repudiate contracts. ${ }^{17}$ The Govrep indicator has a range from 1 to 10 , with larger numbers indicating a lower likelihood of contract repudiation (for our sample, the actual range is 2.68 to 9.77). The average value of Govrep is 9.11 for the 21 OECD countries and 5.62 for the 50 non-OECD countries for which we have data.

Regression results for this exercise are reported in Table 5. The bottom rows of this table present the estimated partial derivative of financial depth with respect to capital account liberalization for different percentiles in the distribution of Govrep. ${ }^{18}$ These results provide support for the hypothesis that capital account liberalization is more likely to promote financial depth when in the presence of better institutional quality. In three of the four cases, capital account liberalization has a significant effect on financial depth at the 95 percent confidence level or better. This occurs at levels of institutional quality higher than 5.30 (for $P R I V Y_{1990 s}^{i}$ in the 1986 to 1995 sample), 6.30 (for $P R I V Y_{1990 s}^{i}$ in the 1976 to 1995 sample), and 7.80 (for $L L Y_{1990 s}^{i}$ in the 1976 to 1995 sample). ${ }^{19}$

\footnotetext{
${ }^{17}$ This series is published by the PRS group and is based on the work of Knack and Keefer (1995).

${ }^{18}$ The value of institutional quality at the given percentiles differs between the 1976 to 1995 and 1986 to 1995 samples, and the values used in constructing the lower part of the table reflect the percentiles for the respective regression samples.

${ }^{19}$ In a related vein, Klein (2005) shows that the effect of capital account liberalization on growth depends upon institutional quality, with a significant and positive effect at higher (although not the highest) levels of institutional quality.
} 
In summary, the baseline results presented in Table 3 of this section show a significant effect of capital account liberalization on financial depth. Further exploration, as shown by the estimates in Tables 4 and 5, indicates that this effect is concentrated among OECD countries, possibly because these countries enjoy better institutional quality than the other countries in the sample. Thus, these findings suggest that the benefits of capital account liberalization are not unconditional, but are likely to depend upon the environment in which the liberalization occurs.

\section{Robustness}

We now examine the robustness of our basic findings with respect to potential endogeneity bias and omitted variable bias. Capital account convertibility is often seen as the logical culmination of developing a deep, mature, and efficient financial system. If this were the case, OLS estimates of $\beta_{1}$ using specification (1) would bias the results toward finding a positive relationship between capital account liberalization and financial depth if countries experience a deepening of their financial system for reasons other than an open capital account while their governments also undertake capital account liberalization. Therefore, it is potentially important to instrument for our measure of capital account liberalization. In what follows, we present instrumental variables estimates of the effect of capital account liberalization on financial depth. We also present other estimates drawn from a specification that includes additional variables which are potentially important for the determination of financial depth and which might be correlated with capital account liberalization. 
The estimates in Table 6 report the instrumental variable analogues to the OLS regressions presented in Table 4. Specifically, we adopt a two-step procedure that first computes $K A L I B_{j}^{f i t, i}$, the fitted value from an OLS regression of $K A L I B_{j}^{i}$ on the chosen instrument and all the other explanatory variables included in equation (1). This fitted value is then used to evaluate the effect of capital account liberalization on financial depth by means of an OLS regression. ${ }^{20}$ The instrument for $K A L I B_{j}^{i}$ is the simple average of an indicator of current account liberalization and an indicator of the requirement to surrender export proceeds, with this average representing the value of the indicators for the period 1979 to 1985 when $j=1986$ to 1995 , and the value of the indicators for the period 1972 to 1975 when $j=1976$ to $1995 .{ }^{21}$ This instrument is always highly significant in the first-stage regressions, with $t$-statistics higher than 4 . As mentioned in the previous paragraph, we would expect to see a smaller responsiveness of financial depth to capital account liberalization if endogeneity plagued our results. However, the instrumental variable estimates reported in the table offer evidence that this is not the case, since the estimated coefficients for the OECD countries tend to be larger than the corresponding OLS estimates. As is typically the case, the standard errors associated with instrumental variables estimates are larger than those obtained with OLS.

\footnotetext{
${ }^{20}$ The standard errors for the estimates reported in Table 6 are too conservative because they $\mathrm{d}$ not take into account that $K A L I B_{j}^{f i t, i}$ is estimated, and consequently measured with sampling error.

${ }^{21}$ The indicators for current account liberalization and the surrender of export proceeds are constructed as a share of the number of years considered, in the same fashion as the capital account liberalization measure. We generate a simple $0 / 1$ indicator variable for each country for each year, according to whether the restrictions were in place or not. We use lines E1 and E4 from the Summary Table of the IMF's Exchange Arrangements and Exchange Restrictions.
} 
Table 7 addresses concerns of potential omitted variable bias by extending the specification used in Table 4 with a range of additional variables appropriate for the sample period. These variables include the logarithm of initial real per capita income (either $\ln Y_{76}$ or $\ln Y_{86}$ ), the growth of income per capita over the sample period (either $\Delta \ln Y_{76-95}$ or $\Delta \ln Y_{86-95}$ ), the average inflation over the sample period (either $\pi_{76-95}$ or $\left.\pi_{86-95}\right)$, and three dummy variables related to legal origin, LegalGermany, LegalFrance, and LegalUK (thus, the omitted legal origin dummy variable is the one for Scandinavian origin). All of these variables are potentially correlated with the dependent variable in our regression. For example, previous research has indicated a link between inflation and financial development (Boyd, Levine and Smith 2001). Legal origin, as well, has been shown to be a determinant of financial development (LaPorta et al., 1997, 1998). Likewise, a country's level of financial depth may depend on a country's growth experience and development, with faster-growing or richer countries requiring a higher degree of financial intermediation. ${ }^{22}$ Note, however, that omission of these variables will bias the estimate for $\beta_{1}$ in equation (1) only to the extent that these variables exhibit a correlation with capital account liberalization.

The estimates presented in Table 7 show that, even with the inclusion of these additional variables, capital account liberalization retains its significant contribution to financial depth. The estimated effect of capital account liberalization on financial depth among the OECD countries is marginally smaller when the additional control variables are included in three of the four cases, but in all four instances the coefficients remain

\footnotetext{
${ }^{22}$ This point will become important for the regressions presented in the next section, which draw a link from capital account liberalization to financial depth to economic growth.
} 
significant at better than the 95 percent level of confidence. We also note that there is no consistent pattern in the statistical significance of any of the variables added to the specification in Table 7. For example, income growth is significant only for the regressions that cover the longer sample period while inflation is only significant for the regressions in which the dependent variable is $L L Y$.

Overall, we find that the results of the previous section are robust to the modifications in the specification presented here. Capital account liberalization continues to have an important role in the determination of financial depth for the OECD countries included in the cross-section. We next turn to an analysis of the way in which capital account liberalization, by promoting financial deepening, contributes to economic growth.

\section{Capital Account Liberalization and Growth}

So far, our results have established a link between capital account liberalization and financial depth, holding constant a range of other possible contributory factors. Ultimately, an important source of the interest in financial depth resides in its impact on economic growth. In this section, we quantify the contribution of capital account liberalization to economic growth through its effect on financial depth.

The specification we use draws on the results presented above concerning the effect of capital account liberalization on financial depth. The growth regression takes the form

$$
\Delta \ln Y_{76-95}^{i} \equiv \ln \left(\frac{Y_{95}^{i}}{Y_{76}^{i}}\right)=\alpha_{0}+\alpha_{1} F D_{1990 s}^{i}+\alpha_{2} \ln Y_{76}^{i}+\alpha_{3} \mathbf{Z}^{i}+u^{i}
$$


where $Y_{j}^{i}$ represents real per capita income for country $i$ in year $j\left(j=1976\right.$ or 1995), $\mathbf{Z}^{i}$ includes Trade $_{76}$, the log of secondary school enrollment in country $i$ in 1976, School $_{76}$, and regional dummy variables for East Asia and Africa. This growth equation is estimated jointly with an equation describing financial depth,

$$
F D_{1990 s}^{i}=\beta_{0}+\beta_{1} K A L I B_{j}^{i}+\beta_{2} \mathbf{X}^{i}+\beta_{3} \Delta \ln Y_{76-95}^{i}+\varepsilon^{i}
$$

This is the same as equation (1) in the previous section, except for the fact that we allow for potential feedback from growth to financial depth by explicitly including $\Delta \ln Y_{76-95}^{i}$ among the regressors. As in the previous section, the vector $\mathbf{X}^{i}$ includes indicator variables for the regions of Africa, Latin America, and for oil-producing countries, in addition to the initial levels of trade and financial depth. The system of two equations, (1') and (2), is estimated using three-stage least squares. The results for the growth regression (2), with one set of estimates using $L L Y$ and the other using PRIVY as indicators of financial depth, are presented in panel $A$ of Table $8 .{ }^{23}$ Panel $B$ of the table reports estimation results for the financial depth equation (1'), again for $L L Y$ and PRIVY respectively.

The results in Table 8 show that there is a significant and positive effect of financial depth on economic growth for the period 1976 to 1995 in this cross section of countries. This finding is consistent with previous empirical literature on the importance of the role of financial depth for economic growth (e.g. King and Levine 1992). But the focus here is on the effect of capital account liberalization on growth via financial deepening. From equations (2) and (1'), it is possible to see that this effect is given by

\footnotetext{
${ }^{23}$ Data availability constrains us to 70 observations, rather than the 73 available when we only run the financial depth regressions over the 1976 to 1995 period.
} 
$a_{1} \beta_{1} /\left(1-\alpha_{1} \beta_{3}\right)$. We then estimate that an increase in $K A L I B_{76-95}^{i}$ from zero to the mean value in the sample of the non-zero observations of 0.40 would lead to a change in per capita income growth over the years 1976 to 1995 of approximately 3.0 percentage points when $L L Y$ is used as an indicator of financial depth, and to a change of 5.5 percentage points when PRIVY is used. The economic relevance of these estimates is evident when we compare them to the sample mean value of per capita income growth of 22.1 percent over the period.

Overall, the results in this section confirm an important link from financial development to economic growth. However, the results of the previous section suggest that capital account liberalization appears to positively affect financial depth, and therefore economic growth, only in the subsample of highly industrialized economies. Thus, the estimated economically sizable link from open capital account to increased growth is not as likely to be present for a less developed country, at least when such a link is presumed to work through an increase in financial depth.

\section{Concluding Remarks}

In this paper we have shown a statistically significant and economically relevant effect of open capital accounts on financial depth and economic growth in a cross-section of developed and developing countries over the periods 1986 to 1995 and 1976 to 1995 . Countries with open capital accounts over some part or all of these periods enjoyed a significantly greater increase in financial depth than countries with continuing capital account restrictions. 
We have also shown, however, that capital account liberalization may not provide the same benefits to all. In particular, the positive relationship between capital account liberalization and financial depth seems to be concentrated among highly developed countries. There is little evidence of capital account liberalization promoting financial depth outside of this group of countries. This may suggest that the benefits of capital account liberalization are only fully realized if this policy change occurs in the presence of adequate institutions and sound macroeconomic policies. A complete understanding of the importance of the policy, institutional, and economic environment that is required for successful liberalization and integration into the world economy, however, calls for a more complete understanding of the manner in which openness alters the performance of an economy. 


\section{Bibliography}

Bagehot, Walter, Lombard Street, 1873, Richard D. Irwin, Homewood, Illinois.

Beck, Thorsten, Asli Demirguc-Kunt and Ross Levine, “The Financial Structure Database," in Asli Demirguc-Kunt and Ross Levine, editors, Financial Structure and Economic Growth: A Cross-Country Comparison of Banks, Markets and Development, MIT Press, Cambridge, MA, c. 2001, pp. 17 - 80.

Bencivenga, Valerie, and Bruce D. Smith, "Financial Intermediation and Endogenous Growth," Review of Economic Studies, vol. 58 (2), 1991, pp. 195 - 209.

Boyd, John H., Ross Levine and Bruce D. Smith, "The Impact of Inflation on Financial Sector Performance,” Journal of Monetary Economics, vol. 47, 2001, pp. 221 - 248.

Chinn, Menzie D. and Hiro Ito, "Capital Account Liberalization, Institutions, and Financial Development: Cross-Country Evidence," NBER Working Paper no. 8967, June 2002.

De Gregorio, José, "Financial Integration, Financial Development, and Economic Growth," Estudios de Economía, vol. 26 (2), pp. 137 - 161, December 1999.

de Swaan, Tom, "International Capital Flows: Discussion," in Jane Sneddon Little and Giovanni P. Olivei, eds., Rethinking the International Monetary System, Federal Reserve Bank of Boston, Conference Series No. 43, June 1999, pp. 163 - 169.

Edison, Hali, Michael Klein, Luca Ricci and Torsten Sløk, "Capital Account Liberalization and Economic Performance: Survey and Synthesis," IMF Staff Papers, vol. 51 (2), August 2004, pp. 220 - 256.

Greenwood, Jeremy, and Bojan Jovanovic, "Financial Development, Growth, and the Distribution of Income," Journal of Political Economy, vol. 98, 1990, pp. 1076 - 1107.

Grilli, Vittorio and Gian Maria Milesi-Ferretti, "Economic Effects and Structural Determinants of Capital Controls," IMF Staff Papers, vol. 42 (3), September 1995, pp. $517-551$.

Hicks, John A., A Theory of Economic History, Oxford University Press, Oxford, England, 1969.

King, Robert and Ross Levine, "Finance and Growth: Schumpeter Might be Right," Quarterly Journal of Economics, vol. 108 (3), August 1993, pp. 717 - 737.

Klein, Michael W., "Capital Account Openness, Institutional Quality and Economic Growth,” NBER Working Paper no. 11,112, February 2005. 
Knack, Stephen, and Philip Keefer, "Institutions and Economic Performance: CrossCountry Tests Using Alternative Institutional Measures," Economics and Politics, vol. 7, 1995, pp.207 - 227.

La Porta, Raphael, Lopez-de-Silanes, Florencio, Shleifer, Andrei, and Robert Vishny, "Legal Determinants of External Finance," Journal of Finance, vol. 52 (3), 1997, pp. $1131-1150$.

pp. $1113-1155$. , “Law and Finance,” Journal of Political Economy, vol. 106, 1998,

Levine, Ross, "Financial Development and Economic Growth: Views and Agenda," Journal of Economic Literature, vol. 35, June 1997, pp. 688 - 726.

Levine, Ross, Norman Loayza and Thorsten Beck, "Financial Intermediation and Growth: Causality and Causes," Journal of Monetary Economics, August 2000, vol. 46, pp. $31-77$.

Levine, Ross and Sara Zervos, "Stock Markets, Banks and Economic Growth," American Economic Review, vol. 88 (3), June 1998, pp. 537 - 558.

McKinnon, Ronald, Money and Capital in Economic Development, Washington, D.C., Brookings Institution, 1973.

Prasad, Eswar S., Kenneth Rogoff, Shang-Jin Wei and Ayhan Kose, Effects of Financial Globalizationon Developing Countries, IMF Occasional Paper no. 220, September 2003.

Quinn, Dennis, "The Correlates of Change in International Financial Regulation," American Political Science Review, vol. 91 (3), September 1997, pp. 531 - 551.

Rajan, Raghuram and Luigi Zingales, "Financial Dependence and Growth," American Economic Review, vol. 88 (3), June 1998, pp. 559 - 586.

Rodrik, Dani, 1998, "Who Needs Capital-Account Convertibility?” in Stanley Fischer, et al., Should the IMF Pursue Capital Account Convertibility? Essays in International Finance, No. 207, International Finance Section, Department of Economics, Princeton University, Princeton, N.J., (May). , Making Openness Work: The New Global Economy and the Developing Countries, Overseas Development Council, Washington, DC, 1999.

Schumpeter, Joseph A., The Theory of Economic Development, 1912, Harvard University Press, Cambridge, MA.

Summers, Lawrence, "International Financial Crises: Causes, Prevention, and Cures," American Economic Review, vol. 90 (2), May 2000, pp. 1 - 16. 


\section{Data Appendix}

The source for the financial indicators $L L Y$ and PRIVY is Beck, Demirguc-Kunt, and Levine (2001). The data can be downloaded at

http://www.worldbank.org/research/projects/finstructure/database.htm

The source for $K A L I B_{1976-1995}^{i}$ and $K A L I B_{1986-1995}^{i}$ is the IMF Exchange Arrangements and Exchange Restrictions (various issues). Section 2 in the text provides details on how these variables are constructed.

The level and growth rate of per capita GDP, the ratio of the sum of imports and exports to GDP, and secondary school enrollment come from the World Bank World Development Indicators (2000). The source for the variable measuring the degree to which governments do not repudiate contracts, GovRep, is Knack and Keefer (1995) from the International Country Risk Guide.

The following is a list of countries included in the empirical analysis of Sections 3 and 4 (with country codes in parentheses). Countries that are not members of the OECD as of 1986 are grouped by region (Continental Africa, Middle East, East Asia, South Asia, and Western Hemisphere, respectively), while the last group lists OECD member countries:

Africa (sub-Saharan): Burkina Faso, Central African Republic, Cote d'Ivoire, Cameroon, The Congo, Ethiopia, Gabon, Ghana, Kenya, Lesotho, Madagascar, Mauritania, Mauritius, Malawi, Niger, Nigeria, Sudan, Senegal, Sierra Leone, Swaziland, Chad, Togo, Uganda, South Africa, Democratic Republic of the Congo, Zambia.

Middle East: Algeria, Egypt, Israel, Jordan, Syria.

South Asia: Bangladesh, India, Sri Lanka, Nepal, Pakistan. Samoa.

East Asia: Fiji, Indonesia, Republic of Korea, Malaysia, Philippines, Thailand,

Latin America: Argentina, Bahamas, Bolivia, Brazil, Barbados, Chile, Costa Rica, Dominica, Dominican Republic, Ecuador, Guatemala, Honduras, Jamaica, Mexico, Nicaragua, Panama, Peru, Paraguay, El Salvador, Trinidad and Tobago, Uruguay, St. Vincent and the Grenadines, Venezuela.

OECD members: Australia, Austria, Belgium, Canada, Denmark, Finland, France, Germany, Greece, Iceland, Ireland, Italy, Japan, Netherlands, New Zealand, Norway, Portugal, Spain, Sweden, United Kingdom, United States. 
Table 1

Financial Depth: Summary Statistics

\section{A. LLY - Liquid Liabilities as a Ratio of GDP}

\begin{tabular}{|c|c|c|c|c|c|}
\hline & $L L Y_{76}$ & $L L Y_{86}$ & $L L Y_{1990 s}$ & $\begin{array}{c}\text { Percent Change } \\
1976-1995\end{array}$ & $\begin{array}{c}\text { Percent Change } \\
1986-1995\end{array}$ \\
\hline Full Sample & .36 & .45 & .46 & 31.2 & 3.6 \\
& $(73)$ & $(95)$ & $(95)$ & $(73)$ & $(95)$ \\
\hline Industrial Countries & .57 & .61 & .68 & 18.8 & 11.6 \\
& $(21)$ & $(21)$ & $(21)$ & $(21)$ & $(21)$ \\
\hline Developing Countries & .28 & .40 & .40 & 41.4 & 0.2 \\
& $(52)$ & $(74)$ & $(74)$ & $(52)$ & $(74)$ \\
\hline
\end{tabular}

\section{B. PRIVY - Financial Intermediaries' Private Sector Claims as a Ratio of GDP}

\begin{tabular}{|c|c|c|c|c|c|}
\hline & $P R I V Y_{76}$ & PRIVY & PRIV $Y_{19905}$ & $\begin{array}{c}\text { Percent Change } \\
1976-1995\end{array}$ & $\begin{array}{c}\text { Percent Change } \\
1986-1995\end{array}$ \\
\hline Full Sample & .25 & .30 & .25 & 49.2 & 15.5 \\
& $(73)$ & $(95)$ & $(95)$ & $(73)$ & $(95)$ \\
\hline Industrial Countries & .43 & .52 & .43 & 54.2 & 27.7 \\
& $(21)$ & $(21)$ & $(21)$ & $(21)$ & $(21)$ \\
\hline Developing Countries & .17 & .23 & .17 & 44.1 & 7.7 \\
& $(52)$ & $(74)$ & $(74)$ & $(52)$ & $(74)$ \\
\hline
\end{tabular}

Note: $L L Y_{1990 s}$ and $P R I V Y_{1990 s}$ denote average values for the period 1991-1995. Samples sizes are in parentheses. 
Table 2

Capital Account Liberalization Index

A. $K A L I B_{86-95}$ and Years of Open Capital Markets $\left(K A L I B_{86-95} \neq 0\right)$

\begin{tabular}{|c|c|c|c|}
\hline$K A L I B_{86-95}$ & Years Open & OECD Countries & Non-OECD Countries \\
\hline 0.1 & 1995 & Norway & Costa Rica, Niger \\
\hline 0.2 & 1994-95 & Spain & Trinidad \& Tobago \\
\hline 0.3 & $1993-95$ & Portugal, Sweden & Argentina, Honduras, Peru \\
\hline 0.4 & $1992-95$ & Ireland & \\
\hline 0.5 & $1991-95$ & Finland, Austria & \\
\hline \multirow[t]{2}{*}{0.6} & $1990-95$ & France, Italy & \\
\hline & $1988-92,1995$ & & Ecuador \\
\hline \multirow[t]{2}{*}{0.7} & $1989-95$ & & Guatemala \\
\hline & $1986-92$ & & Uruguay \\
\hline 0.8 & $1988-95$ & Denmark & \\
\hline 1.0 & $1986-95$ & $\begin{array}{l}\text { Australia, Belgium, Canada, } \\
\text { Germany, Japan, Netherlands, } \\
\text { New Zealand, U.K., U.S. }\end{array}$ & $\begin{array}{l}\text { Bahrain, Bolivia, Indonesia, } \\
\text { Malaysia, Panama, Saudi } \\
\text { Arabia, Singapore }\end{array}$ \\
\hline
\end{tabular}

B. The Evolution of Capital Account Restrictions, 1976-1984

\begin{tabular}{|c|c|c|c|}
\hline \multicolumn{4}{|c|}{ COUNTRIES WITH OPEN CAPITAL ACCOUNTS IN 1976} \\
\hline & OECD Countries & \multicolumn{2}{|c|}{ Non-OECDCountries } \\
\hline & $\begin{array}{l}\text { Belgium, Canada, Germany, } \\
\text { Netherlands, US }\end{array}$ & \multicolumn{2}{|c|}{$\begin{array}{l}\text { Bahrain, Bolivia, Ecuador, Guatemala, Honduras, } \\
\text { Indonesia, Iran, Malaysia, Mexico, Nicaragua, } \\
\text { Panama, Venezuela, Saudi Arabia }\end{array}$} \\
\hline \multicolumn{4}{|c|}{ COUNTRIES CHANGING CAPITAL ACCOUNT RESTRICTIONS } \\
\hline \multirow[t]{2}{*}{ Year } & OECD Countries & \multicolumn{2}{|c|}{ Non-OECD Countries } \\
\hline & Opening Cap. Account & Opening Cap. Account & Closing Cap. Account \\
\hline 1978 & & $\begin{array}{l}\text { Peru, Singapore, } \\
\text { Uruguay }\end{array}$ & Iran, Nicaragua \\
\hline 1979 & Japan, UK & & \\
\hline 1980 & & Costa Rica & Guatemala, Honduras \\
\hline 1981 & & & Bolivia \\
\hline 1982 & & Paraguay & Costa Rica, Mexico \\
\hline 1984 & Australia, New Zealand & & $\begin{array}{l}\text { Paraguay, Peru, } \\
\text { Venezuela }\end{array}$ \\
\hline
\end{tabular}

Source: IMF Exchange Arrangements and Exchange Restrictions, various issues. 
Table 3

Financial Depth and Capital Account Liberalization

\begin{tabular}{|c|c|c|c|c|c|}
\hline \multicolumn{4}{|c|}{$1986-1995$} & \multicolumn{2}{|c|}{ 1976-1995 } \\
\hline & (1) & (2) & & (3) & (4) \\
\hline & $L L Y_{1990 s}$ & $P R I V Y_{1990 s}$ & & $L L Y_{1990 s}$ & $P R I V Y_{1990 s}$ \\
\hline$K A L I B_{86-95}$ & $\begin{array}{l}.0885 * * * \\
(.0300)\end{array}$ & $\begin{array}{l}.1258 * * * \\
(.0379)\end{array}$ & $K A L I B_{76-95}$ & $\begin{array}{l}.1040 * * \\
(.0420)\end{array}$ & $\begin{array}{l}.2670 * * * \\
(.0577)\end{array}$ \\
\hline$F D_{86}$ & $\begin{array}{l}.5907 * * * \\
(.0564)\end{array}$ & $\begin{array}{l}.8429 * * * \\
(.0797)\end{array}$ & $F D_{76}$ & $\begin{array}{l}.5126 * * * \\
(.0872)\end{array}$ & $\begin{array}{l}.6547 * * * \\
(.1170)\end{array}$ \\
\hline Trade $_{86}$ & $\begin{array}{l}.0008 * * * \\
(.0002)\end{array}$ & $\begin{array}{c}.0001 \\
(.0003)\end{array}$ & Trade $_{76}$ & $\begin{array}{l}.0013 * * * \\
(.0003)\end{array}$ & $\begin{array}{c}.0003 \\
(.0005)\end{array}$ \\
\hline Africa & $\begin{array}{l}-.1408 * * * \\
(.0323)\end{array}$ & $\begin{array}{l}-.0847 * * \\
(.0380)\end{array}$ & Africa & $\begin{array}{l}-.2141 * * * \\
(.0416)\end{array}$ & $\begin{array}{l}-.1440 * * * \\
(.0544)\end{array}$ \\
\hline Latin America & $\begin{array}{l}-.1127 * * * \\
(.0288)\end{array}$ & $\begin{array}{l}-.0400 \\
(.0349)\end{array}$ & Latin America & $\begin{array}{l}-.1806 * * * \\
(.0373)\end{array}$ & $\begin{array}{l}-.1827 * * * \\
(.0485)\end{array}$ \\
\hline Oil & $\begin{array}{l}-.1424 * * * \\
(.0379)\end{array}$ & $\begin{array}{l}-.1831 * * * \\
(.0465)\end{array}$ & Oil & $\begin{array}{l}-.1016 * * \\
(.0450)\end{array}$ & $\begin{array}{l}-.1680 * * * \\
(.0609)\end{array}$ \\
\hline Obs. & 95 & 95 & Obs. & 73 & 73 \\
\hline$A d j . R^{2}$ & .83 & .78 & Adj. $R^{2}$ & .77 & .68 \\
\hline
\end{tabular}

Note: $F D$ denotes the relevant measure of financial depth, $L L Y$ or PRIVY. A constant is included in all the regressions. Standard error in parentheses. $* *$ indicates significance at the 95 percent level of confidence. $* * *$ indicates significance at the 99 percent level of confidence. 
Table 4

Financial Depth and Capital Account Liberalization: Assessing the Experience of OECD Countries

\begin{tabular}{|c|c|c|c|c|c|}
\hline \multicolumn{4}{|c|}{ 1986-1995 } & \multicolumn{2}{|c|}{ 1976-1995 } \\
\hline & (1) & (2) & & (3) & (4) \\
\hline & $L L Y_{1990 s}$ & PRIVY $1990 s$ & & $L L Y_{1990 s}$ & $P R I V Y_{1990 s}$ \\
\hline$K A L I B_{86-95}$ & $\begin{array}{c}.0370 \\
(.0380)\end{array}$ & $\begin{array}{c}.0182 \\
(.0433)\end{array}$ & $K A L I B_{76-95}$ & $\begin{array}{c}.0541 \\
(.0585)\end{array}$ & $\begin{array}{l}.1548 * \\
(.0807)\end{array}$ \\
\hline$F D_{86}$ & $\begin{array}{l}.5873 * * \\
(.0556)\end{array}$ & $\begin{array}{l}.7313 * * * \\
(.0797)\end{array}$ & $F D_{76}$ & $\begin{array}{l}.5861 * * * \\
(.1001)\end{array}$ & $\begin{array}{l}.5054 * * * \\
(.1380)\end{array}$ \\
\hline Trade $_{86}$ & $\begin{array}{l}.0009 * * \\
(.0003)\end{array}$ & $\begin{array}{l}.0006 * \\
(.0003)\end{array}$ & Trade $_{76}$ & $\begin{array}{l}.0013 * * * \\
(.0004)\end{array}$ & $\begin{array}{c}.0007 \\
(.0005)\end{array}$ \\
\hline Africa & $\begin{array}{l}-.1397 * * \\
(.0339)\end{array}$ & $\begin{array}{c}-.0815 * * \\
(.0362)\end{array}$ & Africa & $\begin{array}{c}-.2372 * * * \\
(.0418)\end{array}$ & $\begin{array}{l}-.1384 * * \\
(.0558)\end{array}$ \\
\hline Latin America & $\begin{array}{l}-.1017 * * \\
(.0316)\end{array}$ & $\begin{array}{l}-.0092 \\
(.0345) \\
\end{array}$ & Latin America & $\begin{array}{c}-.1915 * * * \\
(.0390)\end{array}$ & $\begin{array}{l}-.1350 * * \\
(.0528)\end{array}$ \\
\hline Oil & $\begin{array}{l}-.1241 * * \\
(.0391)\end{array}$ & $\begin{array}{c}-.1296 * * * \\
(.0449)\end{array}$ & Oil & $\begin{array}{l}-.1004 * * \\
(.0455)\end{array}$ & $\begin{array}{l}-.1264 * * \\
(.0624)\end{array}$ \\
\hline$O E C D_{86}$ & $\begin{array}{l}-.0413 \\
(.0498)\end{array}$ & $\begin{array}{l}-.0126 \\
(.0581)\end{array}$ & $O E C D_{86}$ & $\begin{array}{c}-.1190 * * \\
(.0549)\end{array}$ & $\begin{array}{c}.0621 \\
(.0750)\end{array}$ \\
\hline$K_{A L I B_{86-95}} * O E C D_{86}$ & $\begin{array}{l}.1404 * * \\
(.0708) \\
\end{array}$ & $\begin{array}{l}.2672 * * * \\
(.0813) \\
\end{array}$ & $K A L I B_{76-95} * O E C D_{86}$ & $\begin{array}{l}.1610^{*} \\
(.0876) \\
\end{array}$ & $\begin{array}{r}.1713 \\
(.1208) \\
\end{array}$ \\
\hline Obs. & 95 & 95 & Obs. & 73 & 73 \\
\hline $\operatorname{Adj.} R^{2}$ & .83 & .81 & $A d j . R^{2}$ & .78 & .69 \\
\hline
\end{tabular}

Estimates of the Effect of $K A L I B$ for OECD countries

\begin{tabular}{|l|l|l|l|l|l|}
\hline KALIB $_{86-95}+$ KALIB $_{86-95} * O E C D_{86}$ & $\begin{array}{l}.1775^{* * *} \\
(.0598)\end{array}$ & $\begin{array}{l}.2854 * * * \\
(.0689)\end{array}$ & $K{ }^{2} I B_{76-95}+$ KALIB $_{76-95} * O E C D_{86}$ & $\begin{array}{l}.2152^{* * *} \\
(.0654)\end{array}$ & $\begin{array}{l}.3261^{* * *} \\
(.0899)\end{array}$ \\
\hline
\end{tabular}

Note: FD denotes the relevant measure of financial depth, $L L Y$ or PRIVY. A constant is included in all the regressions.

Standard error in parentheses. * indicates significance at the 90 percent level of confidence. ** indicates significance at the 95 percent level of confidence. $* * *$ indicates significance at the 99 percent level of confidence. 
Table 5

Financial Depth and Capital Account Liberalization:

Assessing the Impact of Governance

\begin{tabular}{|c|c|c|c|c|c|}
\hline \multicolumn{4}{|c|}{ 1986-1995 } & \multicolumn{2}{|c|}{ 1976-1995 } \\
\hline & (1) & (2) & & (3) & (4) \\
\hline & $L L Y_{1990 s}$ & PRIVY $1990 \mathrm{~s}$ & & $L L Y_{1990 s}$ & PRIVY $1990 \mathrm{~s}$ \\
\hline$K_{A L I B_{86-95}}$ & $\begin{array}{c}.0069 \\
(.1440)\end{array}$ & $\begin{array}{c}.0583 \\
(.1684)\end{array}$ & $K A L I B_{76-95}$ & $\begin{array}{l}-.2632 \\
(.4052)\end{array}$ & $\begin{array}{l}-.0481 \\
(.2678)\end{array}$ \\
\hline$F D_{86}$ & $\begin{array}{l}.6114 * * * \\
(.0703)\end{array}$ & $\begin{array}{l}.6708 * * * \\
(.0943)\end{array}$ & $F D_{76}$ & $\begin{array}{l}.4052 * * * \\
(.1053)\end{array}$ & $\begin{array}{l}.3644 * * * \\
(.1347)\end{array}$ \\
\hline Trade $_{86}$ & $\begin{array}{c}.0006 * \\
(.0003)\end{array}$ & $\begin{array}{l}-.0003 \\
(.0003)\end{array}$ & Trade $_{76}$ & $\begin{array}{l}.0012 * * * \\
(.0004)\end{array}$ & $\begin{array}{c}.0001 \\
(.0005)\end{array}$ \\
\hline Africa & $\begin{array}{c}-.1526 * * * \\
(.0430)\end{array}$ & $\begin{array}{l}-.0720 \\
(.0464)\end{array}$ & Africa & $\begin{array}{c}-.2401 * * * \\
(.0507)\end{array}$ & $\begin{array}{l}-.0970 \\
(.0636)\end{array}$ \\
\hline Latin America & $\begin{array}{c}-.1059 * * * \\
(.0373)\end{array}$ & $\begin{array}{l}-.0575 \\
(.0415)\end{array}$ & Latin America & $\begin{array}{c}-.1756 * * * \\
(.0432)\end{array}$ & $\begin{array}{l}-.1251 * * \\
(.0538)\end{array}$ \\
\hline Oil & $\begin{array}{l}-.0712 \\
(.0468)\end{array}$ & $\begin{array}{l}-.0621 \\
(.0554)\end{array}$ & Oil & $\begin{array}{l}-.0643 \\
(.0563)\end{array}$ & $\begin{array}{l}-.0554 \\
(.0731)\end{array}$ \\
\hline Govrep & $\begin{array}{c}.0056 \\
(.0098)\end{array}$ & $\begin{array}{l}.0275^{* * *} \\
(.0121)\end{array}$ & Govrep & $\begin{array}{c}.0012 \\
(.0121)\end{array}$ & $\begin{array}{l}.0496 * * * \\
(.0161)\end{array}$ \\
\hline KALIB $_{86-95} *$ Govrep & $\begin{array}{c}.0085 \\
(.0187) \\
\end{array}$ & $\begin{array}{c}.0129 \\
(.0219) \\
\end{array}$ & KALIB $_{76-95} *$ Govrep & $\begin{array}{l}.0456^{*} \\
(.0255)\end{array}$ & $\begin{array}{c}.0327 \\
(.0333)\end{array}$ \\
\hline Obs. & 71 & 71 & Obs. & 65 & 65 \\
\hline$A d j . R^{2}$ & .86 & .84 & Adj. $R^{2}$ & .80 & .75 \\
\hline
\end{tabular}

\section{Estimates of the Impact of $K A L I B$ at Different Values of Govrep}

\begin{tabular}{|c|c|l|c|c|c|}
\hline $25^{\text {th }}$ Percentile of Govrep & $\begin{array}{c}.0492 \\
\end{array}$ & $\begin{array}{l}.1222^{*} \\
(.0587)\end{array}$ & $25^{\text {th }}$ Percentile of Govrep & $\begin{array}{l}-.0373 \\
(.0896)\end{array}$ & $\begin{array}{l}.1139 \\
(.1132)\end{array}$ \\
\hline $50^{\text {th }}$ Percentile of Govrep & .0615 & $.1409^{* * *}$ & $50^{\text {th }}$ Percentile of Govrep & .0289 & $.1613^{* *}$ \\
& $(.0403)$ & $(.0482)$ & & $(.0587)$ & $(.0764)$ \\
\hline $75^{\text {th }}$ Percentile of Govrep & $.0825^{*}$ & $\begin{array}{l}.1727^{* * *} \\
(.0527)\end{array}$ & $75^{\text {th }}$ Percentile of Govrep & $.1412^{* * *}$ & $.2418^{* * *}$ \\
& $(.0437)$ & & $(.0524)$ & $(.0683)$ \\
\hline $90^{\text {th }}$ Percentile of Govrep & $.0866^{*}$ & $\begin{array}{l}.1790^{* * *} \\
(.0596)\end{array}$ & $90^{\text {th }}$ Percentile of Govrep & $.1636^{* * *}$ & $.2578^{* * *}$ \\
& $(.0497)$ & & $(.0596)$ & $(.0776)$ \\
\hline
\end{tabular}

Note: $F D$ denotes the relevant measure of financial depth, $L L Y$ or $P R I V Y$. A constant is included in all the regressions. Standard error in parentheses. * indicates significance at the 90 percent level of confidence. ** indicates significance at the 95 percent level of confidence. *** indicates significance at the 99 percent level of confidence. 
Table 6

Financial Depth and Capital Account Liberalization:

\section{Instrumental Variables Estimates}

\begin{tabular}{|c|c|c|c|c|c|}
\hline \multicolumn{4}{|c|}{ 1986-1995 } & \multicolumn{2}{|c|}{ 1976-1995 } \\
\hline & (1) & (2) & & (3) & (4) \\
\hline & $L L Y_{1990 s}$ & $P R I V Y_{1990 s}$ & & $L L Y_{1990 s}$ & $P_{R I V Y_{1990 s}}$ \\
\hline$K A L I B_{86-95}^{\text {fit }}$ & $\begin{array}{c}.1077 * \\
(.0647)\end{array}$ & $\begin{array}{c}.1307 * \\
(.0725)\end{array}$ & KALIB $B_{76-95}^{\text {fit }}$ & $\begin{array}{c}-.0003 \\
(.1053)\end{array}$ & $\begin{array}{l}.2531 * \\
(.1446)\end{array}$ \\
\hline$F D_{86}$ & $\begin{array}{l}.5748^{* * * *} \\
(.0647)\end{array}$ & $\begin{array}{l}.6449 * * * \\
(.0861)\end{array}$ & $F D_{76}$ & $\begin{array}{c}.5563 * * * \\
(.1073)\end{array}$ & $\begin{array}{l}.4547 * * * \\
(.1469)\end{array}$ \\
\hline Trade $_{86}$ & $\begin{array}{l}.0008^{* * *} \\
(.0003)\end{array}$ & $\begin{array}{l}.0004 \\
(.0003)\end{array}$ & Trade $_{76}$ & $\begin{array}{c}.0013^{* * *} \\
(.0004)\end{array}$ & $\begin{array}{c}.0005 \\
(.0006)\end{array}$ \\
\hline Africa & $\begin{array}{l}.1295^{* * *} \\
(.0391)\end{array}$ & $\begin{array}{l}-.0758^{*} \\
(.0409)\end{array}$ & Africa & $\begin{array}{c}-.2513 * * * \\
(.0494)\end{array}$ & $\begin{array}{c}-.1101 \\
(.0663) \\
\end{array}$ \\
\hline Latin America & $\begin{array}{l}-.1016^{* * *} \\
(.0344)\end{array}$ & $\begin{array}{l}-.0265 \\
(.0369)\end{array}$ & Latin America & $\begin{array}{l}-.1974 * * * \\
(.0430)\end{array}$ & $\begin{array}{l}-.1438 * * \\
(.0581)\end{array}$ \\
\hline Oil & $\begin{array}{l}-.1393 * * * \\
(.0410)\end{array}$ & $\begin{array}{l}-.1465 * * * \\
(.0462)\end{array}$ & Oil & $\begin{array}{l}-.0887^{*} \\
(.0504)\end{array}$ & $\begin{array}{l}-.1400^{* * *} \\
(.0689)\end{array}$ \\
\hline$O E C D_{86}$ & $\begin{array}{l}-.0334 \\
(.0596)\end{array}$ & $\begin{array}{l}-.0009 \\
(.0672)\end{array}$ & $O E C D_{86}$ & $\begin{array}{l}-.1074 \\
(.0749)\end{array}$ & $\begin{array}{c}.0616 \\
(.1024)\end{array}$ \\
\hline$K^{\prime} A L I B_{86-95}^{f i t} * O E C D_{86}$ & $\begin{array}{r}.1089 \\
(.1060) \\
\end{array}$ & $\begin{array}{l}.2488 * * \\
(.1211) \\
\end{array}$ & $K A L I B_{76-95}^{f i t} * O E C D_{86}$ & $\begin{array}{r}.2025 \\
(.1613) \\
\end{array}$ & $\begin{array}{c}.1824 \\
(.2214) \\
\end{array}$ \\
\hline Obs. & 90 & 90 & Obs. & 72 & 72 \\
\hline $\operatorname{Adj.} R^{2}$ & .82 & .81 & $\operatorname{Adj.} R^{2}$ & .75 & .66 \\
\hline
\end{tabular}

\section{Estimates of the Effect of $K A L I B$ for OECD countries}

\begin{tabular}{|c|c|c|c|c|c|c|}
\hline$K A L I B_{86-95}^{\text {fit }}+K^{\prime} A L I B_{86-95}^{\text {fit }} * O E C D_{86}$ & $\begin{array}{l}.2166^{* *} \\
(.0841)\end{array}$ & $\begin{array}{c}.3795^{* * *} \\
(.0993)\end{array}$ & $K_{A L I B_{76-95}^{\text {fit }}+\text { KALIB }_{76-95}^{\text {fit }} * O E C D_{86}}$ & $\begin{array}{c}.2022 \\
(.1264)\end{array}$ & $\begin{array}{c}.4356^{* *} \\
(.1740)\end{array}$ \\
\hline
\end{tabular}

Note: $F D$ denotes the relevant measure of financial depth, $L L Y$ or PRIVY. KALIB ${ }^{f i t}$ is the fitted value from an OLS regression of $K A L I B$ on the instrument (see main text for detail). A constant is included in all the regressions. Standard error in parentheses.

* indicates significance at the 90 percent level of confidence. ** indicates significance at the 95 percent level of confidence.

$* * *$ indicates significance at the 99 percent level of confidence. 
Table 7

Financial Depth and Capital Account Liberalization:

Augmented Specification

\begin{tabular}{|c|c|c|c|c|c|}
\hline \multicolumn{4}{|c|}{ 1986-1995 } & \multicolumn{2}{|c|}{ 1976-1995 } \\
\hline & $(1)$ & (2) & & $(3)$ & (4) \\
\hline & $L L Y_{1990 s}$ & PRIVY $1990 s$ & & $L L Y_{1990 s}$ & $P R I V Y_{1990 s}$ \\
\hline$K A L I B_{86-95}$ & $\begin{array}{c}.0031 \\
(.0432) \\
\end{array}$ & $\begin{array}{c}.0461 \\
(.0487) \\
\end{array}$ & $K A L I B_{76-95}$ & $\begin{array}{c}.0729 \\
(.05639) \\
\end{array}$ & $\begin{array}{l}.1383^{*} \\
(.0798) \\
\end{array}$ \\
\hline$F D_{86}$ & $\begin{array}{c}.6062^{* * * *} \\
(.0603)\end{array}$ & $\begin{array}{c}.7181 * * * * \\
(.0870)\end{array}$ & $F D_{76}$ & $\begin{array}{c}.4762 * * * \\
(.1065)\end{array}$ & $\begin{array}{l}.3555^{* * *} \\
(.1501)\end{array}$ \\
\hline Trade $_{86}$ & $\begin{array}{l}.0008 * * \\
(.0003) \\
\end{array}$ & $\begin{array}{c}.0002 \\
(.0004) \\
\end{array}$ & Trade $_{76}$ & $\begin{array}{c}.0007 \\
(.0004) \\
\end{array}$ & $\begin{array}{l}-.0001 \\
(.0006)\end{array}$ \\
\hline$O E C D_{86}$ & $\begin{array}{l}.0653 \\
(.0580)\end{array}$ & $\begin{array}{r}-.06222 \\
(.0649) \\
\end{array}$ & $O E C D_{86}$ & $\begin{array}{c}-1558 * * \\
(.0755) \\
\end{array}$ & $\begin{array}{l}-.0063 \\
(.1031) \\
\end{array}$ \\
\hline$K A L I B_{86-95} * O E C D_{86}$ & $\begin{array}{l}.1450^{*} \\
(.0815)\end{array}$ & $\begin{array}{c}.3102 * * * \\
(.0909)\end{array}$ & $K A L I B_{76-95} * O E C D_{86}$ & $\begin{array}{c}.1162 \\
(.0933)\end{array}$ & $\begin{array}{l}.1462 \\
(.1303)\end{array}$ \\
\hline$I N F L_{86-95}$ & $\begin{array}{c}-.0010 * * * \\
(.0003)\end{array}$ & $\begin{array}{c}.0002 \\
(.0004) \\
\end{array}$ & $I^{\prime N F L_{76-95}}$ & $\begin{array}{c}.0019 * * \\
(.0009)\end{array}$ & $\begin{array}{l}-.0014 \\
(.0013) \\
\end{array}$ \\
\hline $\ln Y_{86}$ & $\begin{array}{c}.0007 \\
(.0089) \\
\end{array}$ & $\begin{array}{c}.0135^{* *} \\
(.0102) \\
\end{array}$ & $\ln Y_{76}$ & $\begin{array}{l}.0513^{*} \\
(.0283) \\
\end{array}$ & $\begin{array}{c}.0792 * * \\
(.0395) \\
\end{array}$ \\
\hline$\Delta \ln Y_{86}$ & $\begin{array}{c}.0367 \\
(.0563) \\
\end{array}$ & $\begin{array}{c}.1295 \\
(.0629) \\
\end{array}$ & $\Delta \ln Y_{76}$ & $\begin{array}{c}.1043^{* * *} \\
(.0498) \\
\end{array}$ & $\begin{array}{c}.2074 * * * * \\
(.0692) \\
\end{array}$ \\
\hline LegalGermany & $\begin{array}{l}.1383^{*} \\
(.0811)\end{array}$ & $\begin{array}{l}-.0343 \\
(.0914)\end{array}$ & LegalGermany & $\begin{array}{l}.1759 * * \\
(.0877)\end{array}$ & $\begin{array}{c}.1669 \\
(.1243)\end{array}$ \\
\hline LegalFrance & $\begin{array}{l}.0080 \\
(.0607) \\
\end{array}$ & $\begin{array}{l}-.1235^{*} \\
(.0664) \\
\end{array}$ & LegalFrance & $\begin{array}{c}.0348 \\
(.0674) \\
\end{array}$ & $\begin{array}{l}-.0128 \\
(.0870) \\
\end{array}$ \\
\hline LegalUK & $\begin{array}{l}.0247 \\
(.0638) \\
\end{array}$ & $\begin{array}{l}-.1203^{*} \\
(.0700) \\
\end{array}$ & LegalUK & $\begin{array}{l}.0404 \\
(.0685) \\
\end{array}$ & $\begin{array}{c}.0247 \\
(.0898) \\
\end{array}$ \\
\hline Obs. & 83 & 83 & Obs. & 69 & 69 \\
\hline Adj. $R^{2}$ & .87 & .85 & Adj. $R^{2}$ & .82 & .73 \\
\hline
\end{tabular}

Estimates of the Effect of $K A L I B$ for OECD countries

\begin{tabular}{|c|c|c|c|c|c|}
\hline$K A L I B_{86-95}+K A L I B_{86-}$ & $\begin{array}{l}.1480 * * \\
(.0703)\end{array}$ & $\begin{array}{l}.3563 * * \\
(.0786)\end{array}$ & $K^{\prime} A L I B_{76-95}+K A L I B_{76-95} * O E C D$ & $\begin{array}{l}.1890 * * \\
(.0750)\end{array}$ & $\begin{array}{l}.2845^{* * *} \\
(.1037)\end{array}$ \\
\hline
\end{tabular}

Note: FD denotes the relevant measure of financial depth, $L L Y$ or PRIVY. A constant, regional dummies for Africa and Latin America, and a dummy for oil producing countries are included in all the regressions. Standard error in parentheses. * indicates significance at the 90 percent level of confidence. $* *$ indicates significance at the 95 percent level of confidence. $* * *$ indicates significance at the 99 percent level of confidence. 
Table 8

Simultaneous Equations Estimation of Financial Depth and Growth

A. Growth Regression: Dependent Variable is $\Delta \ln Y_{76-95}$

\begin{tabular}{|c|c|c|c|}
\hline \multicolumn{2}{|c|}{$L L Y$} & \multicolumn{2}{|c|}{$P R I V Y$} \\
\hline$F D_{1990 s}$ & $\begin{array}{l}.6244 * * * \\
(.2167) \\
\end{array}$ & $F D_{1990 s}$ & $\begin{array}{l}.5228 * * \\
(.2262) \\
\end{array}$ \\
\hline $\ln Y_{76}$ & $\begin{array}{l}-.2662 * * * \\
(.0501)\end{array}$ & $\ln Y_{76}$ & $\begin{array}{l}-.2986 * * * \\
(.0511)\end{array}$ \\
\hline Trade $_{76}$ & $\begin{array}{c}.0006 \\
(.0008)\end{array}$ & Trade $_{76}$ & $\begin{array}{l}.0014 * * \\
(.0007)\end{array}$ \\
\hline School $_{76}$ & $\begin{array}{l}.0073 * * * \\
(.0020)\end{array}$ & School $_{76}$ & $\begin{array}{l}.0075 * * * \\
(.0022)\end{array}$ \\
\hline East Asia & $\begin{array}{l}.3084 * * * \\
(.1057)\end{array}$ & East Asia & $\begin{array}{l}.2729 * * \\
(.1150)\end{array}$ \\
\hline Africa & $\begin{array}{l}-.3123 * * * \\
(.0879) \\
\end{array}$ & Africa & $\begin{array}{l}-.3975 * * * \\
(.0832)\end{array}$ \\
\hline Pseudo $\mathrm{R}^{2}$ & 0.64 & Pseudo $\mathrm{R}^{2}$ & 0.65 \\
\hline
\end{tabular}

$B$. Financial Depth Regression: Dependent Variable is $F D_{1990 s}$

\begin{tabular}{|c|c|c|c|}
\hline \multicolumn{2}{|c|}{$L L Y$} & \multicolumn{2}{|c|}{$P R I V Y$} \\
\hline$\Delta \ln Y_{76-95}$ & $\begin{array}{c}.0953 \\
(.0688) \\
\end{array}$ & $\Delta \ln Y_{76-95}$ & $\begin{array}{c}.0566 \\
(.1012) \\
\end{array}$ \\
\hline$K A L I B_{76-95}$ & $\begin{array}{l}.1205^{* * *} \\
(.0393)\end{array}$ & $K A L I B_{76-95}$ & $\begin{array}{l}.2633 * * * \\
(.0572)\end{array}$ \\
\hline$F D_{76}$ & $\begin{array}{l}.5070 * * * \\
(.0789)\end{array}$ & $F D_{76}$ & $\begin{array}{l}.6567 * * * \\
(.1143)\end{array}$ \\
\hline Trade $_{76}$ & $\begin{array}{l}.0010 * * * \\
(.0003)\end{array}$ & Trade $_{76}$ & $\begin{array}{c}.0001 \\
(.0005)\end{array}$ \\
\hline Africa & $\begin{array}{l}-.1616 * * * \\
(.0498)\end{array}$ & Africa & $\begin{array}{l}-.1165 \\
(.0721)\end{array}$ \\
\hline Latin America & $\begin{array}{l}-.1654 * * * \\
(.0379)\end{array}$ & Latin America & $\begin{array}{l}-.1760 * * * \\
(.0545)\end{array}$ \\
\hline Oil & $\begin{array}{l}-.0877 * * \\
(.0453)\end{array}$ & Oil & $\begin{array}{l}-.1567 * * \\
(.0665)\end{array}$ \\
\hline Pseudo $R^{2}$ & 0.81 & Pseudo $R^{2}$ & 0.71 \\
\hline Observations & 70 & Observations & 70 \\
\hline
\end{tabular}

Estimation with 3 Stage Least Squares. 